\title{
Influences of Deforestation on Carbon Balance in a Natural Tropical Peat Swamp Forest in Thailand
}

\author{
Satoru Suzuki, Tomoyasu Ishida, ${ }^{*}$ Toshihide Nagano and Surin WaIJARoen** \\ Faculty of International Agricultural and Food Studies, Tokyo University of Agriculture, \\ Setagaya-ku, Tokyo 156-8502, Japan \\ * Faculty of Agriculture, Utsunomiya University, Utsunomiya 321-8505, Japan \\ ** Department of Land Development, Ministry of Agriculture and Cooperative, \\ Bangkok 10900, Thailand
}

(Received December 3, 1998)

\begin{abstract}
The effects of deforestation on carbon balance in a natural tropical peat swamp forest were evaluated by micrometeorological monitoring. The monitoring sites were the primary forest at To-Daeng and the secondary forest at Bacho in Narathiwat Province, Thailand. The concentration gradient method (CG) and the relaxed eddy accumulation method (REA) were used to estimate the $\mathrm{CO}_{2}$ flux above the canopies. We estimated the annual amount of carbon absorption for both sites, using the relationship between $\mathrm{CO}_{2}$ flux and solar radiation for each site. An annual net carbon absorption of $5.32 \mathrm{t} \mathrm{C} \mathrm{ha}^{-1}$ year $^{-1}$, was estimated for the primary forest. The accumulation of the released organic matter from the forest into logged-water caused the net carbon absorption in the peat swamp forest. In the secondary forest, annual net carbon absorption was estimated at 5.22 t C $\mathrm{ha}^{-1}$ year $^{-1}$, which is almost the same range of absorption as the primary forest, because of plant growth in the secondary forest. A greater quantity of net carbon absorption, $9.69 \mathrm{t}$ $\mathrm{C} \mathrm{ha}{ }^{-1}$ year $^{-1}$, was expected, assuming that the ground surface remained water-logged throughout the year. On the other hand, assuming it remained dry throughout the year, a net carbon emission of $-0.40 \mathrm{t} \mathrm{C} \mathrm{ha}^{-1}$ year $^{-1}$, was expected.
\end{abstract}

\section{INTRODUCTION}

Peatland is an important carbon store for global carbon balance. Although the peatland areas amount to about $3 \%$ of the land surface, the amount of carbon accumulated in the peat is estimated at $329-528 \mathrm{Gt}$, which is equal to about $20 \%$ of the total amount of carbon in the global soil store (Maltby and Proctor, 1996) or about $60 \%$ of atmospheric carbon.

There are approximately 0.4 million $\mathrm{km}^{2}$ of tropical peatlands in Southeast Asia, which account for approximately $70 \%$ of tropical peatlands worldwide (Rieley et al., 1996). The wide distribution of peatlands is one feature of tropical forest areas in Southeast Asia. Many of the peatlands are covered with peat swamp forest in tropical areas. However, there is little information on their vegetation, plant community structure and environmental characteristics. This may be because of permanent water-logging, dense vegetation and inaccessibility. On the other hand, natural peat swamp forest has been developed for agricultural use or lumber production and converted to fields for cultivation, wastelands and/or secondary forests.

It is important to note that the deforestation of peat swamp forest and successive conversion to secondary forest brings higher temperatures and drier conditions to the region because 
of changes in the heat balance (Nagano et al., 1995, 1996 ; Suzuki et al., 1997). This suggests that the carbon emission to the atmosphere from the soil is altered because a change in temperature and soil moisture influences the decomposition rate of the soil's organic matter (e.g. Nakane, 1980; Jenkinson et al., 1991). The influence of deforestation on carbon balance, particularly for peat swamp forests may be more serious due to decomposition of the peat soil.

There are previous estimates of field-level $\mathrm{CO}_{2}$ exchange for forests by the accumulation method or simulation using some models (McMurtrie and Wolf, 1983; Nakane and Yamamoto, 1983; Yoda, 1989; Ryan, 1990; Bonan, 1992). The micrometeorological approach to $\mathrm{CO}_{2}$ exchange is less common (Aoki et al., 1975; Fan et al., 1990 ; Monji et al., 1996). Little is known about the nature of carbon balance for peat swamp forest.

\section{MATERIALS AND METHODS}

1. Experimental site. In Thailand, there exists 64000 ha of peat swamp area on the southeast coast and on the Malay Peninsula, 70\% of which is concentrated in Narathiwat Province. In the province, only 8000 ha of the swamp area remains as primary forest while the rest of it has been developed for agricultural uses or converted to wasteland and/or secondary forest. The experiments were carried out at two sites of different vegetation cover in the province, namely (1) To-Daeng $\left(6^{\circ} 4^{\prime} 30^{\prime \prime} \mathrm{N}, 101^{\circ} 58^{\prime} 20^{\prime \prime} \mathrm{E}\right)$, a natural tropical peat swamp forest area, (2) Bacho $\left(6^{\circ} 30^{\prime} 22^{\prime \prime} \mathrm{N}, 101^{\circ} 44^{\prime} 42^{\prime \prime} \mathrm{E}\right)$, a secondary forest area.

Figure 1 shows the precipitation in To-Daeng and Narathiwat City, near Bacho. The region has a short monsoon season, with heavy rainfall concentration in November and December and a relatively dry season from January to April. In this paper, the climate is divided into a dry season (from January to April inclusive), a rainy season (November and December), and a intermediate season (from May to October inclusive). Narathiwat City has about $2400 \mathrm{~mm}$ annual average precipitation and $27.6^{\circ} \mathrm{C}$ annual average temperature.

To-Daeng is located about $5 \mathrm{~km}$ north of Sungaikolok, near the Malaysian border. The forest is primary and under conservation by the government. According to Suzuki and Hara (1995), the stand was composed of 31 tree species, belonging to 17 families and 26 genera. The stem number was $719 /$ ha (diameter at breast height: $\mathrm{DBH}>10 \mathrm{~cm}$ ). The canopy is fully closed and has its maximum density between 9 and $13 \mathrm{~m}$. The uppermost storey was mainly composed of Ganua motoreyana and the under storey was mainly composed of Eugenia

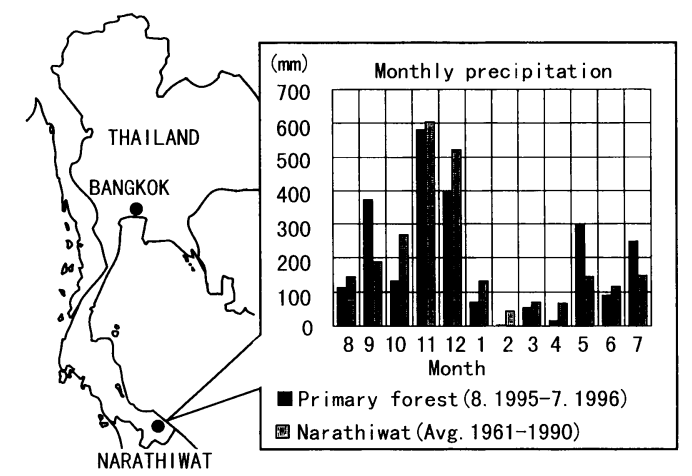

Fig. 1 Research site and precipitation at the site.

Primary forest : monthly precipitation at To-Daeng research site. Narathiwat: monthly average precipitation measured at Narathiwat Meteorological Station near the research site for the secondary forest. 
tumida. These 2 species account for more than $50 \%$ of both the number and the basal area. The mean canopy height was approximately $25 \mathrm{~m}$, with a few isolated tree tops reaching to about $30 \mathrm{~m}$. Above ground biomass was estimated at $245 \mathrm{t} \mathrm{ha}^{-1}$ of dry weight (described as $\mathrm{t} D W \mathrm{ha}^{-1}$ in this paper). Peat was the uppermost layer of the forest soil and accumulated less than $3 \mathrm{~m}$ on the marine clay layer. The forest was water-logged throughout the year and the water depth was from 0.05 to $0.9 \mathrm{~m}$.

Bacho is located near Narathiwat City and about $60 \mathrm{~km}$ from the primary forest. The original forest had been clearly cut and the ponding water had been drained to develop agricultural land since the 1970's. However, most of the land could not be used for agriculture because the $\mathrm{pH}$ of the soil turned strongly acid due to oxidation of the sulfur in the peat layer. There is no ponding water above the soil surface except in the rainy season because of drainage. The water level was observed at $60 \mathrm{~cm}$ under the surface at its lowest in the dry season and $60 \mathrm{~cm}$ ponding water at its highest above the surface in the rainy season. The stand was mainly composed of Melaleuca cajuputi and several kinds of grasses, Eleocharis spiralis, Blechnum indicum, Scleria sumatrensis. This region had been repeatedly burned and the average height of the stand had recovered to $2.5 \mathrm{~m}$ through 4 years in April 1996. Above ground biomass was estimated at $12.0 \mathrm{t} D W \mathrm{ha}^{-1}$ in April 1996. LAI of Melaleuca cajuputi was estimated at 0.32 in April 1996. The thickness of the peat layer had decreased to less than $2 \mathrm{~m}$ because of accelerated decomposition and repeated burning after development.

2. Methods. The concentration gradient method (described as CG in this paper) and the relaxed eddy accumulation method (described as REA in this paper) were used to estimate the $\mathrm{CO}_{2}$ flux above the canopies. Continuous automatic measurement by the concentration gradient method for the long-term was attempted. Manual measurements were periodically carried out by the relaxed eddy accumulation method.

Concentration gradient method(CG): The $\mathrm{CO}_{2}$ flux, $F_{\mathrm{CO}_{2}}\left(\mathrm{~g} \mathrm{CO}_{2} \mathrm{~m}^{-2} \mathrm{~s}^{-1}\right)$, using $\mathrm{CG}$ is given

$$
F_{\mathrm{CO}_{2}}=-K_{\mathrm{CO}_{2}} \frac{\Delta C}{\Delta Z}
$$

where, $K_{\mathrm{CO}_{2}}$ is the turbulent diffusive coefficient of $\mathrm{CO}_{2}\left(\mathrm{~m}^{2} \mathrm{~s}^{-1}\right), \Delta C$ and $\Delta Z$ are the difference of $\mathrm{CO}_{2}$ concentration $\left(\mathrm{g} \mathrm{CO}_{2} \mathrm{~m}^{-3}\right)$ and elevation $(\mathrm{m})$. In this study, the diffusive coefficient of the sensible heat $\left(K_{\mathrm{H}}\right)$ was substituted for $K_{\mathrm{CO} 2}$ due to the fact that the diffusive coefficient of sensible heat and $\mathrm{CO}_{2}$ are generally similar (e.g. McBean, 1992).

$K_{\mathrm{H}}$ can be calculated from the sensible heat flux $(H)$ measured by the eddy correlation method as Eq. (2) or Bowen ratio method as Eq. (3).

$$
\begin{aligned}
& K_{\mathrm{CO}_{2}}=K_{\mathrm{H}}=-\overline{W T} \frac{\Delta Z}{\Delta T} \\
& K_{\mathrm{CO}_{2}}=K_{\mathrm{H}}=\left(\frac{-\left(R_{\mathrm{n}}-G-Q\right)}{\frac{0.622 \rho l \Delta e}{P_{\mathrm{atm}}}+\rho C_{\mathrm{p}} \Delta T}\right) \Delta Z
\end{aligned}
$$

where $W T$ is the covariance of vertical wind velocity and temperature. $R_{\mathrm{n}}, G$ and $Q$ are the heat balance elements $\left(\mathrm{kW} \mathrm{m}^{-2}\right)$, which are net radiation, heat flux in the soil and heat flux storage in the plant vegetation, respectively. The value of 0.622 is the ratio of the molecular masses of water vapor and dry air. $P_{\text {atm }}, \rho, l$ and $e$ are the atmospheric pressure (hPa), the air density $\left(\mathrm{kg} \mathrm{m}^{-3}\right)$, the latent heat of vaporization of water $\left(\mathrm{J} \mathrm{kg}^{-1}\right)$ and the water vapor pressure $(\mathrm{hPa})$, respectively. $\quad C_{\mathrm{p}}$ is the specific heat of air $\left(\mathrm{J}^{\circ} \mathrm{C}^{-1} \mathrm{~kg}^{-1}\right)$.

Relaxed eddy accumulation method (REA): REA was theoretically proposed to measure scalar fluxes using conditional sampling (Businger and Oncley, 1990). This method bypasses the need for rapid measurements of the gas concentration, $C$, necessary for the eddy 
correlation method (described as EC in this paper). Using REA, the $\mathrm{CO}_{2}$ flux, is obtained by

$$
F_{\mathrm{CO}_{2}}=b \sigma_{\mathrm{w}}\left(C_{\mathrm{up}}-C_{\mathrm{dn}}\right)
$$

where $b$ is an empirical coefficient that is determined by experiment and $\sigma_{\mathrm{w}}$ is the standard deviation of vertical wind velocity during a statistically meaningful sampling period $\left(\mathrm{m} \mathrm{s}^{-1}\right)$. $C_{\mathrm{up}}$ and $C_{\mathrm{dn}}$ are average concentrations of $\mathrm{CO}_{2}\left(\mathrm{~g} \mathrm{CO}_{2} \mathrm{~m}^{-3}\right)$ transported by upward wind and by downward wind during the period. The coefficient $b$ can be calculated assuming the simultaneous equality of the sensible heat flux estimated by EC and by REA (Ishida et al., 1995). Thus, Eqs. (5) and (6) were obtained.

$$
H=\rho C_{\mathrm{p}} \overline{W T}=\rho C_{\mathrm{p}} b \sigma_{\mathrm{w}}\left(T_{\mathrm{up}}-T_{\mathrm{dn}}\right) .
$$

The solution for $b$ is

$$
b=\frac{\overline{W T}}{\sigma_{\mathrm{w}}\left(T_{\mathrm{up}}-T_{\mathrm{dn}}\right)}
$$

where $T_{\mathrm{up}}$ and $T_{\mathrm{dn}}$ are the average temperatures of upward wind and downward wind during the period.

3. Experimental set-up. An observation tower $38 \mathrm{~m}$ high was constructed in the primary forest. Using this tower, several measurements were conducted. The profiles of air temperature and water vapor pressure above and within canopies were measured with air flow type wet- and dry-bulb thermocouple thermometers (type T). The temperature of the soil, tree stems, and ponding water were also measured with $T$ type thermocouple thermometers. The net radiation and the solar radiation were measured with a net radiometer (Q-6, Campbell Scientific) and photo-cell type radiometers (LI-200SZ, Li-COR), respectively. The abovementioned sensors were attached about $4 \mathrm{~m}$ apart from the tower to prevent wind disturbance and the reflection or emission of radiation from the tower (Kaimal, 1988). The precipitation was measured with a tipping bucket rain gauge (TE525, Campbell Scientific) on the top of the tower. The difference of $\mathrm{CO}_{2}$ concentration between 2 heights, 3.6 and $6.6 \mathrm{~m}$ above the canopy, was measured with a differential type double cell infra-red $\mathrm{CO}_{2}$ analyzer (ZRF, Fuji Electric) positioned in the observation hut. A pair of gas samples for the measurement of the difference were introduced to the $\mathrm{CO}_{2}$ analyzer using $30 \mathrm{~m}$ length polyethylene tubes. Vertical wind velocity variation together with air temperature variation at a height of $3.6 \mathrm{~m}$ above the canopies, was measured at $5 \mathrm{~Hz}$ sampling intervals with two one-dimensional sonic anemome-



Fig. 2 Schematic diagram of the installation for the measurement (the primary forest).

$\ominus$, net radiometer ; $\triangle$, pyranometer; $\bigcirc$, dry bulb; $\bullet$, wet bulb, $\diamond$, thermocouple for water and stem temperature measurement ; $\otimes$, air sample inlet for $\mathrm{CO}_{2}$ measurement ; $\odot$, sonic anemometer ; a, tipping bucket rain gauge; monitoring room. 
ters, one (TR41 and DA-600, Kaijo) for the sensible heat flux measurement by eddy correlation method, another (CA27, Campbell Scientific) for $\mathrm{CO}_{2}$ flux measurement by relaxed eddy accumulation method. Apart from the sonic anemometers, the signals were sampled every 10 $\mathrm{s}$, and $30 \mathrm{~min}$ averages were recorded by data loggers (CR21X, Campbell Scientific). The sensors were attached to the tower as shown in Fig. 2.

The same sensors used in the primary forest were attached to a $4 \mathrm{~m}$ high tower in the secondary forest. In addition, a heat flux plate and a $\mathrm{T}$ type thermocouple were placed in the soil $2 \mathrm{~cm}$ below the surface in order to measure the soil heat flux and the soil temperature, respectively.

4. Description of carbon dioxide analyzing system. It was necessary to eliminate the water vapor included in the air sample in order to avoid the cross sensitivity to water vapor of infra-red when we measure the $\mathrm{CO}_{2}$ concentration by using an infra-red $\mathrm{CO}_{2}$ analyzer. The dehumidifying system shown in Fig. 3 was utilized. The system consists of a refrigerator and membrane type dryers (Perma-pure-dryer ZBJ02502, Fuji Electric). The air samples taken using polyethylene tubes at 2 heights were introduced to spiral copper tubes placed in the refrigerator and partly dehumidified due to condensation. Next, the air sample was passed through the Perma-pure-dryer and dehumidified up to smaller than $-10^{\circ} \mathrm{C}$ of dew point. The Perma-pure-dryer is a tube that can remove humidity in proportion to the difference of water vapor pressures between the inside and the outside of the tube. The air sample was introduced into the inside of the tube and the expelled air after measurement by the $\mathrm{CO}_{2}$ analyzer was introduced into the outside of the tube as a purge gas.

Span adjustment of the $\mathrm{CO}_{2}$ analyzer was made at the beginning of a series of $\mathrm{CO}_{2}$ difference measurements. A zero adjustment system for the $\mathrm{CO}_{2}$ analyzer without calibrated gas was developed for automatic long-term measurement. The principle of zero adjustment is that the observed value is corrected by the value of the difference of $\mathrm{CO}_{2}$ concentration between the two air flows from a single inlet divided by solenoid valves. The schematic diagram of the system and the schedule of the system operation are shown in Fig. 4. The difference of $\mathrm{CO}_{2}$ concentration at the 2 heights was measured from 0 to $30 \mathrm{~min}$ for every hour and the zero adjustment system worked from 30 to $50 \mathrm{~min}$, but the data was recorded from 40 to $50 \mathrm{~min}$. The $10 \mathrm{~min}$-period, from 30 to $40 \mathrm{~min}$ and from 50 to $60 \mathrm{~min}$, was for air replacement to avoid mixing the zero adjustment air and the $\mathrm{CO}_{2}$ difference measurement air. The replacement time of 10 min was sufficient to eliminate the disturbance of values by mixing the separate air samples.

5. Description of REA system. A schematic diagram of the gas sampling system of the relaxed eddy accumulation method (REA) is shown in Fig. 5 (Ishida et al., 1995). The system consists of two independent flow channels. Each channel has an inlet, 3-way solenoid

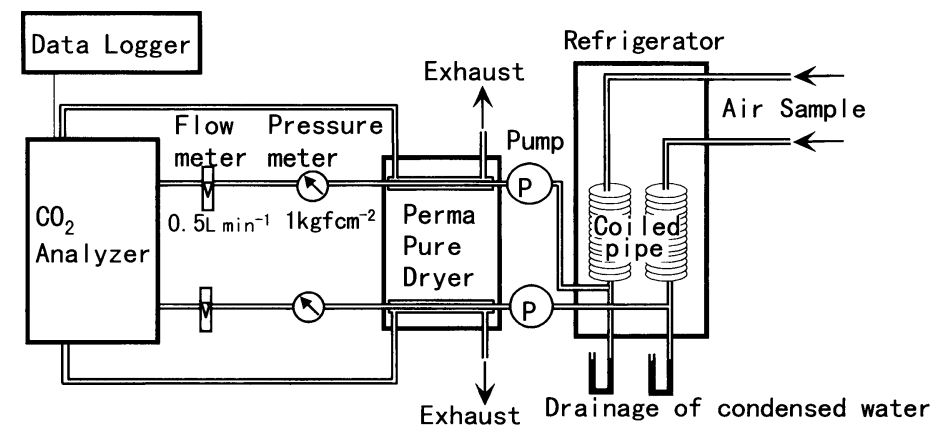

Fig. 3 Dehumidifying system to measure the concentration difference of carbon dioxide. 


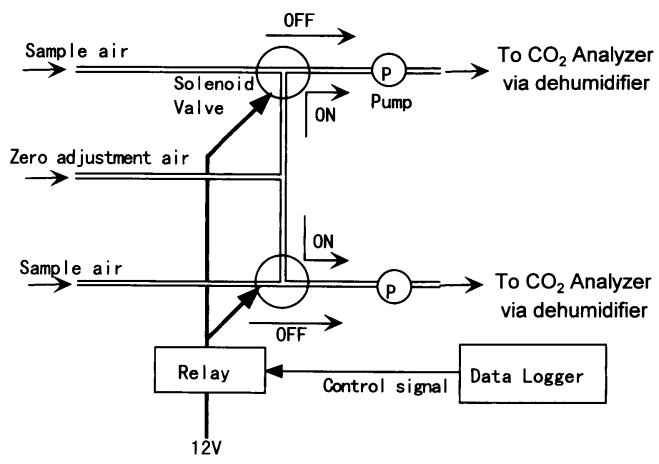

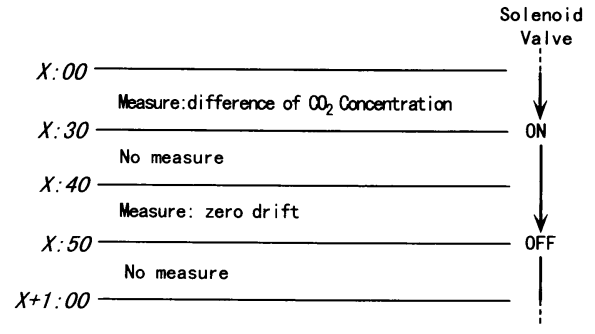

Fig. 4 Zero adjustment system for $\mathrm{CO}_{2}$ analyzer and schedule of control.

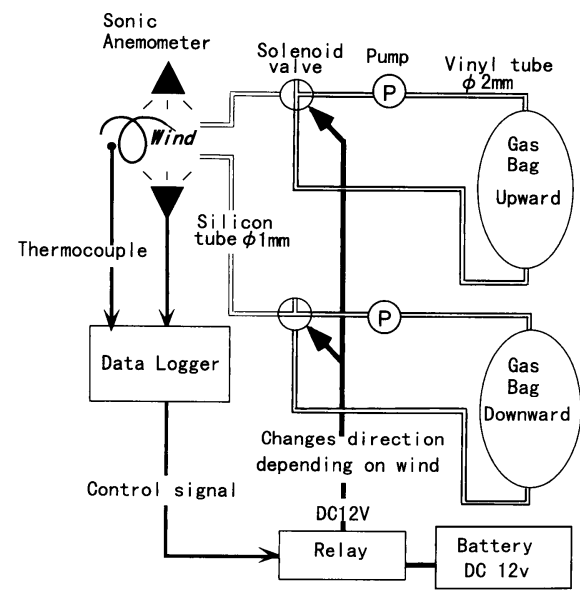

Fig. 5 Schematic diagram of the REA sampling system.

valve (339, Anger Scientific), a pump (MP-15CF, Shibata) and a gas bag $20 \mathrm{~L}$ in volume (Tedlarbag, Sansho). The vertical wind velocity $(w)$ measured by sonic anemometer (CA27, Campbell Scientific) was used to operate the conditional sampling at a constant flow rate by opening one valve to a reservoir when $w$ is positive and another valve to another reservoir when $w$ is negative. The gas sampling using the sonic anemometer and the control of the valves were carried out at the rate of $5 \mathrm{~Hz}$, and the $30 \mathrm{~min}$ standard deviation of the vertical wind velocity was calculated and recorded by data logger (CR21X, Campbell Scientific). The air stored in the reservoir was cycled between the valve and the reservoir while the valve was closed to the reservoir, in order to avoid an overload of the pump and to maintain a continuous flow rate when the valve is open to the reservoir. A pair of gas samples was collected for $30 \mathrm{~min}$ and changed to a new pair in the reservoir. The system was positioned $3.6 \mathrm{~m}$ above the canopy in the primary forest and $1.0 \mathrm{~m}$ above the canopy in the secondary forest.

\section{RESULTS AND DISCUSSION}

\section{Comparison between $C G$ and $R E A$}

A typical daily course of the coefficients, $b, \sigma_{\mathrm{w}}$ and $\left|T_{\mathrm{up}}-T_{\mathrm{dn}}\right|$, for the secondary forest is shown in Fig. 6 (a), (b) and (c). The coefficient $b$ was approximately constant in daytime, with a value equal to 0.54 (Fig. 6(a)). However, a wide scatter of the coefficient $b$ and theoretically unsuitable data, negative $b$, were observed in nighttime. The reason for this is that the data are suspected to have been caused by a failure of estimation of the coefficient $b$ using Eq. (6) because the $\sigma_{\mathrm{w}}$ and $\left|T_{\mathrm{up}}-T_{\mathrm{dn}}\right|$ were near zero in nighttime. A wide scatter of values for the coefficient $b$ was observed in the range of less than $0.3 \mathrm{~m} \mathrm{~s}^{-1}$ for $\sigma_{\mathrm{w}}$ and $0.2^{\circ} \mathrm{C}$ for 

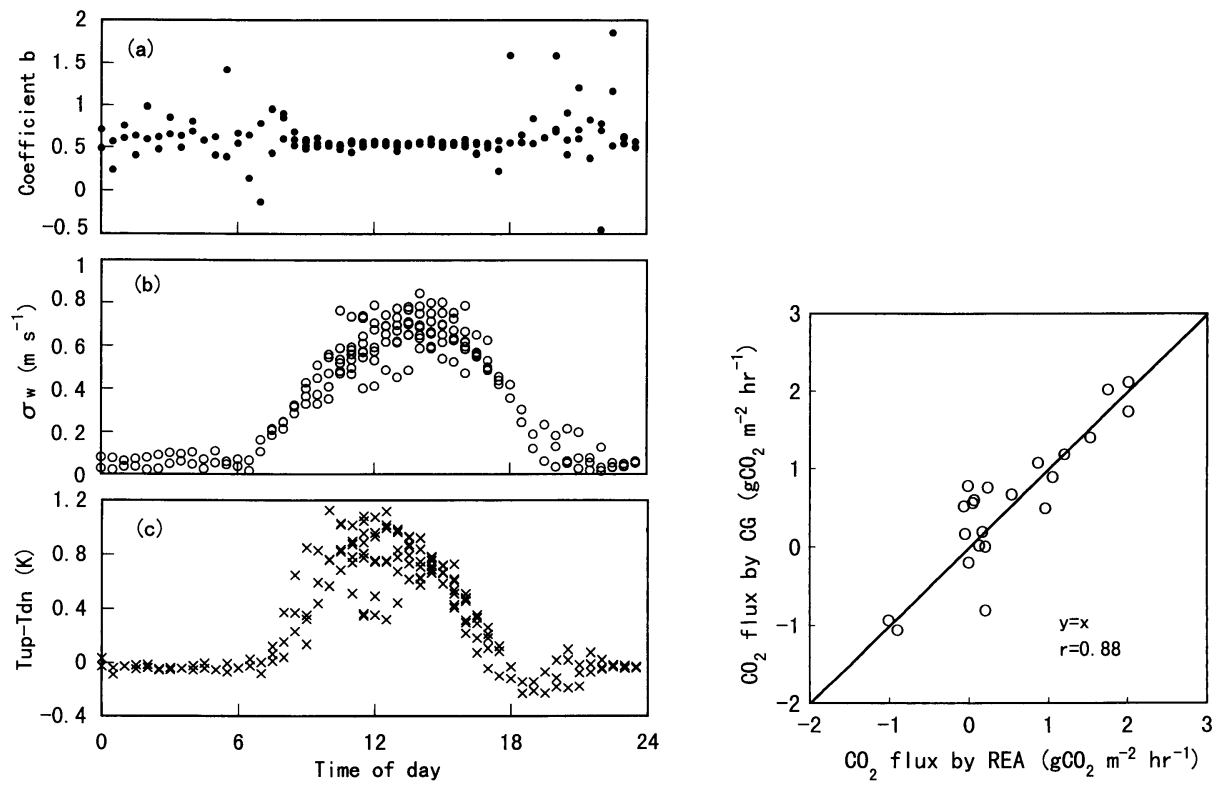

Fig. 6 A typical daily course of the coefficient $b$ for REA and accompanied values in the secondary forest during $18 \mathrm{Apr}$. 1996 to 27 Apr. 1996.

Fig. 7 Comparison of $\mathrm{CO}_{2}$ flux observed in the secondary forest by REA and CG during 11 Oct. 1995 to 13 Oct. 1995.

$1: 1$ line is shown in the figure.

$\left|T_{\text {up }}-T_{\text {dn }}\right|$ (Fig. 6(b), (c)).

Similar to the secondary forest, values of the coefficient $b$ were approximately 0.52 in daytime for the primary forest. The values for coefficient $b$ observed in both sites correlate closely with previous estimates (Businger and Oncley, 1990 ; Baker et al., 1992 ; Pattey et al., 1993,1995; Gao, 1995; Ishida et al., 1995; Hamotani et al., 1996). In this study, these constant values were used to estimate the $\mathrm{CO}_{2}$ flux by REA for each site.

The comparison of the $\mathrm{CO}_{2}$ fluxes estimated by $\mathrm{CG}$ with those by REA in the secondary forest is shown in Fig. 7. The correlation is satisfactorily close over a wide range of fluxes, although the principles of both methods are quite different. This result suggests the satisfactory reliability of both methods and instrumentation used here.

\section{Carbon dioxide flux versus the solar radiation}

Figure 8 shows typical diurnal courses of the $\mathrm{CO}_{2}$ flux in relation to solar radiation above the canopies observed on a clear day in a dry season for both observation sites. Positive fluxes indicate the downward flux of $\mathrm{CO}_{2}$. The expected behavior of negative fluxes (upward flux) during the nighttime and positive fluxes (downward flux) during the daytime is evident, with the sign changes occuring around $1 \mathrm{~h}$ after sunrise and $1 \mathrm{~h}$ before sunset. We recognize the expected courses of the $\mathrm{CO}_{2}$ flux that are similar to the courses of solar radiation for both sites in daytime.

We estimated the diurnal $\mathrm{CO}_{2}$ flux using the data of solar radiation, considering the similarity of diurnal courses of $\mathrm{CO}_{2}$ flux and solar radiation (e.g. Fig. 8). Figure 9 shows the net $\mathrm{CO}_{2}$ flux above each canopy versus solar radiation at the time observed in both observation sites. The $\mathrm{CO}_{2}$ flux increased rapidly at low solar radiation, up to $0.6 \mathrm{~kW} \mathrm{~m}^{-2}$ for the primary forest and $0.4 \mathrm{~kW} \mathrm{~m}{ }^{-2}$ for secondary forest, and increased slightly at high solar radiation. 




Fig. 8 A typical daily course of $\mathrm{CO}_{2}$ flux (dots) and solar radiation (line) on a fine day in the dry season at the primary forest (a) (29 Apr. 1996) and the secondary forest (b) (18 Apr. 1996).

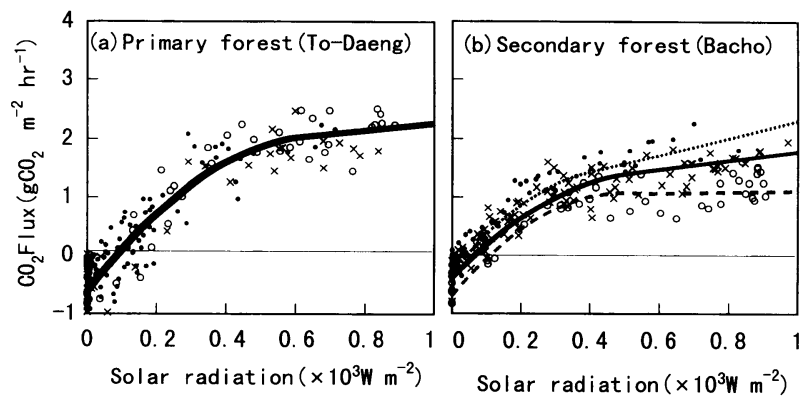

Fig. $9 \mathrm{CO}_{2}$ flux versus solar radiation in the dry season $(\bigcirc)$, the rainy season $(\bigcirc)$, and the intermediate season $(\times)$ at the primary forest (a) and the secondary forest (b).

The water table $(\mathrm{Wt}(\mathrm{cm}))$ from the soil surface for the secondary forest is as follows : dry season, $\mathrm{Wt}<-30$; rainy season, $\mathrm{Wt}>0$; intermediate season, $-30<\mathrm{Wt}<0$. The primary forest was water-logged throughout the year: $0.05<\mathrm{Wt}<90$. In the secondary forest, dashed line, dotted line, and solid line show dry, rainy, and intermediate season, respectively.

It is remarkable that the data of each season for the primary forest could be interpolated by one curve. The reason for this is considered to be that the seasonal change in water conditions for the plant vegetation and the soil was slight, because the ground surface of the primary forest was water-logged throughout the year. Also, the influence on the photosynthetic rate and the respiration by the seasonal change of the air temperature was slight because the annual change of temperature was relatively small, for example, the annual change of daily average temperature at canopy height (height $=25.6 \mathrm{~m}$ ) ranged within $5^{\circ} \mathrm{C}$ (from 23 to $28^{\circ} \mathrm{C}$ inclusive) in a year.

The data observed in the secondary forest could be interpolated by three curves which corresponded to the three seasons; that is, rainy season, dry season and intermediate season. The balance between photosynthetic rate and soil respiration for each season makes the curves different. The $\mathrm{CO}_{2}$ emission from the soil (soil respiration) increased in the dry season because the soil decomposition rate was higher under dry conditions. In addition to this, it was pointed out that Melaleuca cajuputi was under water stress condition when the water table was lower than $30 \mathrm{~cm}$ under the soil surface (Hironaka et al., 1998). Therefore, it is suggested that the photosynthetic rate was slowed due to water stress in the dry season.

In contrast, the soil decomposition rate decreased in the rainy season because it was restricted by the anaerobic conditions of the water-logged soil. Also, it is suggested that the photosynthetic rate was high because of the non-water-stress condition in the rainy season. 
Hironaka et al. (1998) showed a much higher growth rate of stem diameter in the rainy season than in the dry season.

The seasonal averages of observed nocturnal $\mathrm{CO}_{2}$ fluxes for the primary forest were approximately $-0.6 \mathrm{~g} \mathrm{CO}_{2} \mathrm{~m}^{-2} \mathrm{~h}^{-1}$ for each season. In this study, the data was considered to be nocturnal when solar radiation was equal to zero. The seasonal averages of observed nocturnal $\mathrm{CO}_{2}$ flux for the secondary forest were $-0.7,-0.4,-0.3 \mathrm{~g} \mathrm{CO}_{2} \mathrm{~m}^{-2} \mathrm{~h}^{-1}$ for the dry, the intermediate, and the rainy season, respectively. The nocturnal flux in the water logged condition in the secondary forest was half of that in the primary forest. This is because of the different canopy size.

Aoki et al. (1975) observed that $\mathrm{CO}_{2}$ flux above the canopies of tropical rain forest in West Malaysia was $3.5 \mathrm{~g} \mathrm{CO}_{2} \mathrm{~m}^{-2} \mathrm{~h}^{-1}$ at $1.0 \mathrm{~kW} \mathrm{~m}^{-2}$ of solar radiation and $-1.5 \mathrm{~g} \mathrm{CO}_{2} \mathrm{~m}^{-2}$ $\mathrm{h}^{-1}$ at nighttime. Our values are smaller in daytime and greater at nighttime. One reason for this is considered to be the difference of the plant biomass, i.e. the biomass of the primary forest was half of Aoki's observation site, which could cause a lower rate of photosynthesis and plant respiration. Also, water-logged conditions in the primary forest could restrict soil respiration.

\section{Annual net carbon absorption}

Annual courses of monthly net carbon absorption. Figure 10 shows the courses of monthly net carbon absorption for both observation sites during a year from Aug. 1995 to Jul. 1996. The values were converted from the amount of $\mathrm{CO}_{2}$ to carbon. In the primary forest, the net $\mathrm{CO}_{2}$ absorption by the canopies was evaluated from averaged solar radiation for every 30 min and the curve shown in Fig. 9(a) in daytime, and from the average of observed data which is $-0.6 \mathrm{~g} \mathrm{CO}_{2} \mathrm{~m}^{-2} \mathrm{~h}^{-1}$ at nighttime. In the secondary forest, the diurnal net carbon absorption was evaluated from the averaged solar radiation data and the curves corresponded to the season shown in Fig. 9 (b) in daytime and the averages of the data seasonally observed were substituted for nocturnal emission. Although January and February were climatically classified as dry season, these months were regarded as the intermediate season because the ground water level was similar to that of the intermediate season. In the primary forest, larger amounts of net carbon absorption were evaluated in the dry season and smaller or negative

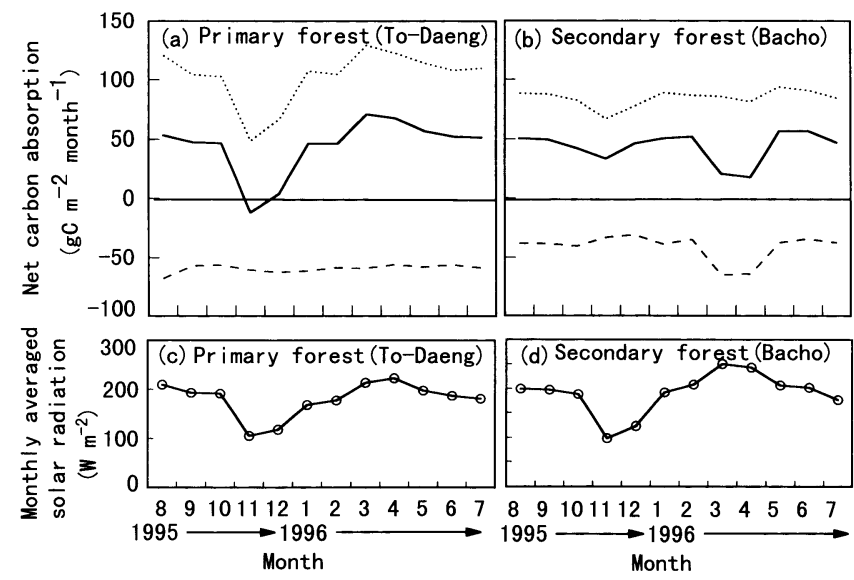

Fig. 10 Annual courses of monthly net carbon absorption and monthly averaged solar radiation at the primary forest (a), (c) and the secondary forest (b), (d). Solid line, dotted line, and dashed line in figures (a) and (b) show the net carbon absorption for the whole day, daytime and nighttime, respectively. 
amounts resulted in the rainy season. In the secondary forest, however, smaller amounts were evaluated in the dry season and the amounts in the rainy season decreased slightly.

In the primary forest, the net absorption at nighttime was similar throughout the year as the dashed line in Fig. 10(a) shows. As the dotted line in Fig. 10(a) shows, however, the amount of net absorption in daytime was larger in the dry season with higher solar radiation and smaller in the rainy season because of lower solar radiation. As a result, net absorption in the dry season was larger than that in the rainy season in the primary forest. Especially, low solar radiation in the rainy season as shown in Fig. 10(c) resulted in low or negative amounts in that season.

The secondary forest in the dry season had less net absorption than in the rainy season as the solid line in Fig. 10(b) shows, even if the solar radiation was higher as shown in Fig. 10(d). The reason for this is that the net carbon absorption at nighttime was less in the dry season as the dashed line in Fig. 10(b) shows because of the increase of the peat decomposition rate depending on soil water conditions. In addition to the peat decomposition, a low photosynthesis rate due to water stress was suggested in the dry season. As a result, the net absorption in the dry season was less than in the other seasons.

It is also noteworthy that in the rainy season the amount of net carbon absorption in the primary forest is much smaller than in the secondary forest. This results from the shape of curves of $\mathrm{CO}_{2}$ flux versus solar radiation shown in Fig. 9 and the low solar radiation in the season. The $\mathrm{CO}_{2}$ flux in the secondary forest in the rainy season is greater than in the primary forest for the range of solar radiation smaller than $0.3 \mathrm{~kW} \mathrm{~m}^{-2}$ (Fig. 9). In addition, a higher frequency of solar radiation ranged in less than $0.3 \mathrm{~kW} \mathrm{~m}^{-2}$ was observed in the rainy season than in the dry season for both sites (Fig. 11). This resulted in larger amounts of net carbon absorption in the rainy season for the secondary forest than for the primary forest. Also, less net absorption in nighttime in the primary forest resulted in much smaller amounts of net absorption than in the secondary forest.

Amount of annual net carbon absorption. The annual net carbon absorption can be
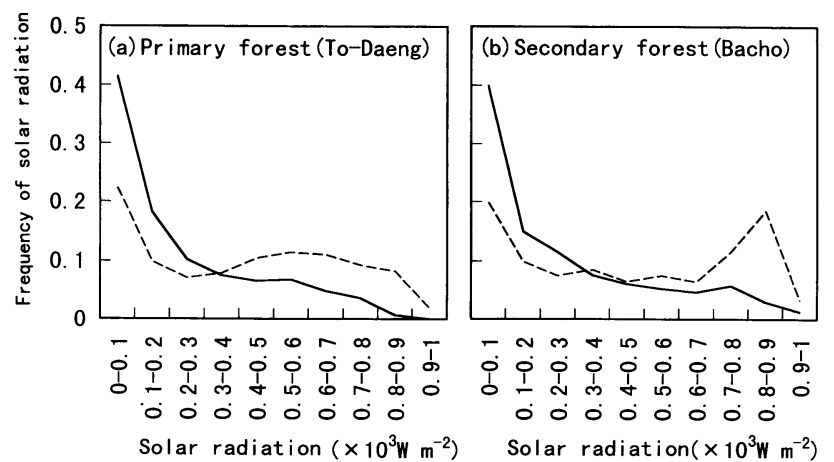

Fig. 11 Distribution of 30-min averaged solar radiation in November and December (solid line), and March and April (dashed line) for the primary forest (a) and the secondary forest (b).

Table 1 Annual net carbon absorption ( $\left.\mathrm{t} \mathrm{C} \mathrm{ha-1} \mathrm{year}^{-1}\right)$.

\begin{tabular}{cccc}
\hline \multirow{2}{*}{ Primary forest } & \multicolumn{3}{c}{ Secondary forest } \\
\cline { 2 - 4 } & Actual & $\begin{array}{l}\text { Dry conditions } \\
\text { through a year }\end{array}$ & $\begin{array}{c}\text { Wet conditions } \\
\text { through a year }\end{array}$ \\
\hline 5.32 & 5.22 & -0.4 & 9.69 \\
\hline
\end{tabular}


estimated at $5.32 \mathrm{t} \mathrm{C} \mathrm{ha}^{-1} \mathrm{year}^{-1}$ as the sum of the monthly net carbon absorption for the primary forest (Table 1). The primary forest could be expected to be mature because the forest had never been artificially disturbed. Mature forest is often assumed to be in a steady state with no net carbon gain or loss (e.g. Yoda, 1989; Whitmore, 1993). It is remarkable that the primary forest has net carbon absorption even if the forest is considered to be under the steady state. Typical mature forest absorbs a large amount of carbon for photosynthesis. However, in addition to respiration, carbon released from the decomposition process of litter fall and fallen trees increases. As a result, they balance and the net carbon absorption is considered to equal zero (Fig. 12(a)). In contrast, a large amount of litter fall and fallen trees in peat swamp forest is stored under water as peat. Thus, the amount of release by the decomposition process is considered to be lower and the net amount of carbon absorption becomes considerable (Fig. 12(b)).

However, the assumption that typical mature forest has no net carbon gain or loss has some uncertainty. Because the biomass and biomass accumulation rates of the forest are always changing due to natural disturbances, i.e. the steady state for mature forest may be observed as an average over a long time and a large area. There are previous estimates that typical mature forest has net carbon gain (Fan et al., 1990; Bonan, 1992). Fan et al. (1990) observed carbon absorption of more than $2 \mathrm{t} \mathrm{C} \mathrm{ha}^{-1} \mathrm{year}^{-1}$ in a mature tropical forest in Brazil. Considering that our estimated value was relatively greater than Fan's value, it is suggested that the mature peat swamp forest absorbs much more carbon than the typical mature forest as long as the peat accumulation process continues. Peat accumulation as a carbon sink is considered to be a special feature of the carbon balance in peat swamp forests.

In the secondary forest, the total amount of net carbon absorption was $5.22 \mathrm{t} \mathrm{C} \mathrm{ha}^{-1}$ year $^{-1}$, which is a similar value to the primary forest (Table 1). Considering that a 1 inch year $^{-1}$ fall in ground level was observed in the secondary forest and $70 \%$ of it was caused by peat decomposition (Kyuma, 1992), the plant growth was the cause of net carbon absorption in the secondary forest because there was no net peat accumulation.

Influences of water management on the net carbon absorption in the secondary forest. We attempted to evaluate the expected net carbon absorption of the secondary forest by using the curve of the dry season and the rainy season through a year. These were expected values

(a) Typical mature forest

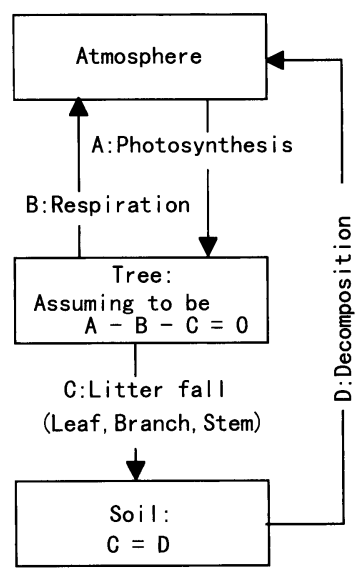

Net carbon absorption $=0$ (A-B-D) (b) Peat swamp forest

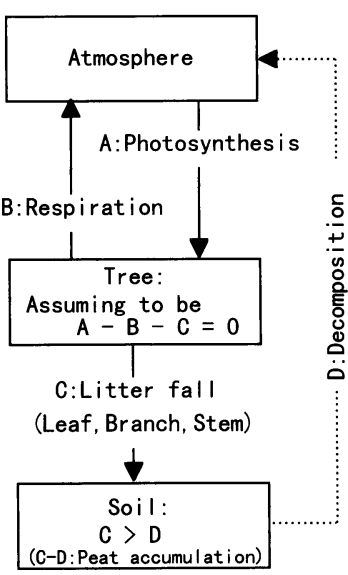

Net carbon absorption $>0$ (A-B-D)

Fig. 12 Schematic diagram of carbon balance for typical mature forest and peat swamp forest. 


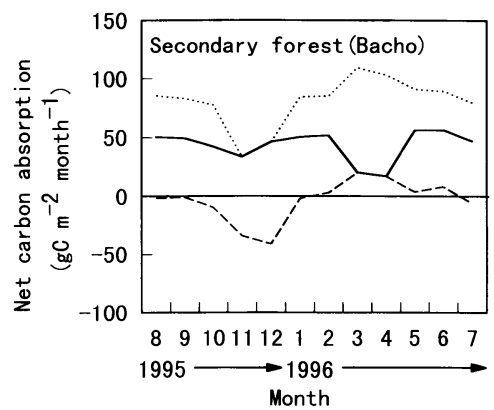

Fig. 13 Annual courses of monthly expected net carbon absorption in the secondary forest.

The solid line shows the actual absorption as shown in Fig. 10(b). Dotted line and dashed line show water-logged and completely drained conditions respectively throughout the year.

that were under dry conditions and water-logged conditions through a year, respectively. The annual courses of the expected net carbon absorption for the secondary forest is shown in Fig. 13. The annual amount of expected net carbon absorption with water-logged ground surface through a year was evaluated at $9.69 \mathrm{t} \mathrm{C} \mathrm{ha}^{-1}$ year $^{-1}$, which is equal to 1.9 times the actual net carbon absorption (Table 1). The annual amount of expected net carbon absorption with complete drainage through a year was evaluated at $-0.40 \mathrm{t} \mathrm{C} \mathrm{ha}^{-1} \mathrm{year}^{-1}$, which means net carbon emission (Table 1). These results show that water management is quite important for the secondary forest, to restrict soil respiration and keep the forest as a carbon sink.

\section{CONCLUSION}

The extent of $\mathrm{CO}_{2}$ flux versus solar radiation was the same during the three seasons; that is, rainy season, dry season and intermediate season in the primary forest. The reason for this is that the seasonal change of water conditions for plant vegetation and soil was slight because the ground surface at the primary forest was water-logged throughout the year. The annual net carbon absorption was estimated at $5.32 \mathrm{t} \mathrm{C} \mathrm{ha}^{-1}$ year $^{-1}$ for the primary forest. The accumulation of litter fall to the ground peat and its restricted decomposition or effluent with water caused a net carbon absorption in the primary forest ecosystem, assuming the live vegetation has reached steady state with no net carbon gain or loss. Even if the primary forest is not under steady state, it is expected that the mature peat swamp forest absorbs much more carbon than the typical mature forests during the continuous peat accumulation in the soil layer. This result indicates a significant feature of the carbon balance for peat swamp forest ; that is, a large amount of continuous net carbon absorption. Considering that global warming is caused by an increase of atmospheric $\mathrm{CO}_{2}$, the peat swamp forest could be a quite important ecosystem as a continuous carbon sink.

The extent of $\mathrm{CO}_{2}$ flux versus solar radiation was different in each of the three seasons for the secondary forest. The balance between photosynthetic rate and soil respiration for each season makes the curve different. In the dry season, the $\mathrm{CO}_{2}$ emission from the soil increased because the soil decomposition rate was higher under dry conditions. Also, it is suggested that the photosynthetic rate was slowed due to water stress because of the lack of soil moisture in the dry season. In the rainy season, soil respiration decreased because soil decomposition was restricted by anaerobic conditions under ponded water. The annual net carbon absorption was estimated at $5.22 \mathrm{t} \mathrm{C} \mathrm{ha}^{-1}$ year $^{-1}$, which is mainly from plant growth in the secondary forest. A greater quantity of net carbon absorption, $9.69 \mathrm{t} \mathrm{C} \mathrm{ha}^{-1} \mathrm{year}^{-1}$, was expected, 
assuming that the ground surface remained under water-logged conditions through the year. On the contrary, a net emission of carbon, $-0.40 \mathrm{t} \mathrm{C} \mathrm{ha}^{-1}$ year ${ }^{-1}$, was expected, assuming that the soil remained under dry conditions through the year. The results show that water management is quite important for the secondary forest to restrict soil respiration and maintain the forest as a carbon sink.

We thank to Prof. Y. Kitaya, Osaka Prefecture University, for his advice in carrying out research in the field and Dr. P.Vijarnsorn, Department of Land Development in Thailand, for careful support in Thailand. We are also grateful to Prof. K. Suzuki, Yokohama National University, and Prof. K. Hara, Tokyo University of Information Sciences for significant ecological information on the peat swamp forest. This work was financially supported by a Grant-in-Aid for Creative Research Studies from the Ministry of Education, Science, Sports and Culture of Japan.

\section{REFERENCES}

Aoki, M., Yabuki, K., Koyama, H. 1975. Micrometeorology and assessment of primary production of a tropical rain forest in West Malaysia. J. Agric. Meteorol. 31 : 115-124.

Baker, J. M., Norman, J. M., Bland, W. L. 1992. Field-scale application of flux measurement by conditional sampling. Agric. Forest Meteorol. 62: 31-52.

Bonan, G. B. 1992. Physiological controls of the carbon balance of boreal forest ecosystems. Can.J. Forest Res. 23 : 1453-1471.

Businger, J. A., Oncley, S. P. 1990. Flux measurement with conditional sampling. J. Atmos. Oce. Tech. 7: $349-352$.

Fan, S. M., Wofsy, S. C., Bakwin, P. S., Jacob, D. J. 1990. Atmosphere-biosphere exchange of $\mathrm{CO}_{2}$ and $\mathrm{O}_{3}$ in the central Amazon forest. J. Geophys. Res. (D) 95 : 16851-16864.

Gao, W. 1995. The vertical change of coefficient $b$, used in the relaxed eddy accumulation method for flux measurement above and within a forest canopy. Atmos. Environ. 29 : 2339-2347.

Hamotani, K., Uchida, Y., Monji, N., Miyata, A. 1996. A system of the relaxed eddy accumulation method to evaluate $\mathrm{CO}_{2}$ flux over plant canopies. J. Agric. Meteorol. 52: 135-139.

Hironaka, T., Ishida, T., Nagano, T., Vijarnsorn, P., Waijaroen, S., Sitthibush, C. 1998. New waterstress index from the change in stem diameter. International Seminar: The Development of Sustainable Biological Production. Technologies in the Problem Soils in Southeast Asia, Aug. p 71-72.

Ishida, T., Nagano, T., Kitaya, Y., Suzuki, S. 1995. Gas flux measurement using the eddy accumulation method with conditional sampling. (Japanese text with English summary) Environ. Control in Biol. 33 : 79-82.

Jenkinson, D. S., Adams, D. E., Wild, A. 1991. Model estimates of $\mathrm{CO}_{2}$ emissions from soil in response to global warming. Nature $351:$ 304-306.

Kaimal, J. C. 1988. The Atmospheric Boundary Layer-Its Structure and Measurement, Indian Institute of Tropical Meteorology. Shivajinagar (tr. by Mitsuta, Y., Yamada, M. 1993. 微細気象学 大気境 界層の構造と観測. (Japanese text) Gihodo, Tokyo, p 66).

Kyuma, K. 1992. Degraded tropical forest ecosystem and its rehabilitation in Southeast Asia. (Japanese text with English summary) Earth and Ecology $4: 20$.

Maltby, E., Proctor, M. C. F. 1996. Peatlands : Their nature and role in the biosphere. In "Global Peat Resources" (ed. by Lappalainen, E). International Peat Society, Kuokkalantie, p 11-20.

McBean, G. A. 1992. Role of active-passive scalar relationships in evaporation from vegetated surfaces. In "Advances in Theoretical Hydrology" (ed. by O'Kane, J. P.). European Geophysical Society, Katlenburg-Lindau, p 47-58.

McMurtrie, R., Wolf, L. 1983. Above- and below-ground growth of forest stands: A carbon budget model. Ann. Bot. 52 : 437-448.

Monji, N., Hamotani, K., Jintana, V. 1996. Characteristics of $\mathrm{CO}_{2}$ flux over a mangrove forest of Southern Thailand in rainy season. J. Agric. Meteorol. 52 : 149-154.

Nagano, T., Ishida, T., Kitaya, Y., Vijarnsorn, P., Suzuki, S. 1996. Micrometeorological research of peat 
swamp forests in Narathiwat, Thailand. Tropics $6(1 / 2): 105-115$.

Nagano, T., Ishida, T., Kitaya, Y., Vijarnsorn, P., Suzuki, S., Waijarurn, S. 1995. Micrometeorological observation of peat swamp forest in Narathiwat, Thailand. In "A Tropical Swamp Forest Ecosystem and Its Greenhouse Gas Emission” (ed. by Vijarnsorn, P., Suzuki, K., Kyuma, K., Wada, E., Nagano, T., Takai, Y.). Nodai Research Institute, Tokyo, p 35-44.

Nakane, K. 1980. A simulation model of the seasonal variation of cycling of soil organic carbon in forest ecosystems. Jpn. J. Ecol. 30: 19-29.

Nakane, K., Yamamoto, M. 1983. Simulation model of the cycling of soil organic carbon in forest ecosystems disturbed by human activities. Jpn. J. Ecol. 33 : 169-181.

Pattey, E., Cessna, A. J., Desjardins, R. L., Kerr, L. A., Rochette, P., St-Amour, G., Zhu, T., Headrick, K. 1995. Herbicides volatilization measured by the relaxed eddy-accumulation technique using two trapping media. Boundary-Layer Meteorol. 76 : 201-220.

Pattey, E., Desjardins, R. L., Rochette, P. 1993. Accuracy of the relaxed eddy-accumulation technique, evaluation using $\mathrm{CO}_{2}$ flux measurements. Boundary-Layer Meteorol. 66: 341-355.

Rieley, J. O., Ahmad-Shah, A. A., Brady, M. A. 1996. The extent and nature of tropical peat swamps. In "Tropical Lowland Peatlands of Southeast Asia" (ed. by Maltby, E., Immirzi, C. P., Safford, R. J.). IUCN, Gland, p 17-54.

Ryan, S. 1990. Diurnal $\mathrm{CO}_{2}$ exchange and photosynthesis of the Samoa tropical forest. Global Biochem. Cycles $4: 69-84$.

Suzuki, K., Hara, K. 1995. Ecological rehabilitation of the tropical swamp forests. In "A Tropical Swamp Forest Ecosystem and Its Greenhouse Gas Emission” (ed. by Vijarnsorn, P., Suzuki, K., Kyuma, K., Wada, E., Nagano, T., Takai, Y.). Nodai Research Institute, Tokyo, p 17-24.

Suzuki, S., Ishida, T., Nagano, T., Matsukawa, S. 1997. Influences of deforestation on radiation and heat balances in tropical peat swamp forest in Thailand. (Japanese text with English summary) Environ. Control in Biol. 35 : 277-284.

Whitmore, T. C. 1990. Tropical Rain Forest. Oxford University Press, Oxford (tr. by Kumazaki, M., Kobayashi, S. 1993. 熱帯雨林総論. (Japanese text) Tsukiji Shokan, Tokyo, p 155-192).

Yoda, K. 1989. Production of tropical forests. In "Botany, Agriculture and Forestry in Southeast Asia”(東南アジアの植物と農林業). (Japanese text) JSPS, Tokyo, p 91-114.

\section{〈和文抄録〉}

\section{タイ国の熱帯泥炭湿地林伐採が炭素収支に及ぼす影響}

\section{鈴木 賞・石田朋靖*・長野敏英・スリン ワイジャロエン**}

東京農業大学国際食料情報学部， *宇都宮大学農学部，**土地開発局（夕イ国）

タイ国半島部ナラチワ県の熱帯泥炭湿地林地帯において原生林および伐採後に成立した二次林 の樹冠上で $\mathrm{CO}_{2}$ フラックスを観測した。 フラックス測定は濃度傾度法および定速渦累積法を併用 し，1995 年 8 月から 1996 年 7 月の期間における正味炭素吸収量を推定した。原生林，二次林それ

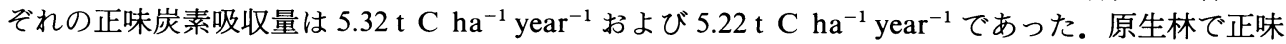
に炭素吸収が行われている原因は, 落枝, 落葉, 倒木等が湛水下に泥炭として蓄積され分解が遅れ るためと推察された.二次林における正味の炭素吸収は, 植物の成長によるものであると考えられ た。また, 二次林において, 湛水を通年維持した場合には $9.69 \mathrm{t} \mathrm{C} \mathrm{ha}^{-1} \mathrm{year}^{-1}$, 排水を徹底し土壌 を通年乾燥状態に維持した場合は $-0.40 \mathrm{t} \mathrm{C} \mathrm{ha}^{-1} \mathrm{year}^{-1}$ (正味の放出）と推定された。 